\title{
The Relevance of the Application of the Neural Approaches in the Premature Detection of the Banking Difficulties: Case of Tunisia
}

\author{
Niazi Kammoun \& Chanez Charfi \\ University of Sfax (Tunisia), Higher School of Business \\ Airport Road, 1081, Sfax 3018, Tunisia
}

Received: Jan. 30, 2013 Accepted: April 8, 2013 Published: June 1, 2013

doi:10.5296/ajfa.v5i1.3417ＵRL: http://dx.doi.org/10.5296/ajfa.v5i1.3417

\begin{abstract}
:
We propose in this study to test the relevance of the use of an early warning system (EWS) for banking difficulties in the Tunisian case. This model is based on the use of a multilayer neural network with a back-propagation algorithm. From a sample of 18 Tunisian banks, we try to establish the different ratios of the financial health of banks, extracted from CAMEL rating system. With a good ranking percentage obtained for the total sample of more than $93 \%$, we conclude that neural networks are found to be robust for the prediction of the fragility of the Tunisian banks.
\end{abstract}

Keywords: Bank Performance; Bankruptcy Prediction Models; Artificial Neural Networks. JEL Classification: G21, G33 


\section{Introduction}

One week after the decrease of the rating of the long-term debt by Tunisia of two notches to BB, the Standards and Poor's rating agency announced, on May 2012, the reduction in the rating of five Tunisian banks. This relates to the Arab Tunisian Bank (ATB), the Bank of Housing (BH), the Tuniso-Kuwaiti bank (BTK), The Tunisia and Emirates Bank (BTE) as well as the Tunisian Banking Company (STB). The decision is considerable as far as ratings are supposed to measure the probability of failure, be it in an industrial company or a bank. Their role is even more fundamental in emerging countries, where the regulatory and institutional environment tends to create incentives for a better risk management (Rojas-Suarez, 2000; 2001).

Although the Tunisian banking system has played a leading role in the development of the Tunisian economy, it has witnessed many difficulties particularly the present-day high level of banking bad debts. In 2010, the part of the bad debts in the total of bank credits remained very high (12.1\%), a value which reveals a big gap if compared with the other emerging countries (Chile $2.7 \%$, Malaysia $3.4 \%$, and Turkey $3.2 \%$ ). Besides, the rate of funding of the bad debts was $59.6 \%$, far from the rate of $70 \%$ set as an objective by the Central Tunisian Bank (CTB) to the horizon of 2012 and below the levels reached by other emerging countries. The quality of the banking debts reveals a structural problem from which the Tunisian banking sector suffers. The Tunisian banks are characterized by an inadequacy between the nature of the debts and the funding made. Fitch Ratings, as well as the IMF, consider that the Tunisian banks were not well funded (International Monetary Fund [IMF], 2006).

This situation shows that the Tunisian banks became vulnerable because they did not manage to adjust to the new context in which they have to survive. The latter is characterized by important structural changes induced by a process of opening and of financial liberalization. As result, they were less dynamic because they didn't meet the requirements of the banking economic efficiency.

The consolidation of the banking system can be possible by the improvement of the quality of the credit portfolio which includes a relatively high volume of bad debts compared with the international standards, and this is true in spite of the effort made to reduce their part in the commitment total. The public authorities' strategic choice to free the monetary policy has become a reality through a rather careful approach and this is by establishing standards concerning solvency, division of the risks and liquidity. The adoption of these prudent standards leads banks to grant credits with more rationality and discipline and incites them to strengthen their stockholders' equity and provide the necessary reserves. The overall objective is to prepare an easy passage to Basel II rules.

Considering the harmful effects that a banking crisis can have_not only at the level of the economic activity but also at the social level_the prediction of the bankruptcy of banking institutions has been the subject of several empirical works. They are based on the economic and financial analysis of the failing and the solvent banks so as to determine basic indicators which are indispensable to alert countries to the outbreak of a crisis and allow them to manage their financial sector and their economy better. For example, having noticed that the 
non-performance translated in terms of fragility can increase the default risk of a bank, certain authors, such as Barr and Siems (1994), Goyeau and Tarazi (1992) and Pantalone and Platt (1987), tried to establish prediction models of the failure and to determine its explanatory factors. They have asserted that the failure of banks can be accounted for by internal micro-economic factors. This has led to the use of variables from the CAMEL typology which was originally created by the American banking authorities of regulation and supervision at the beginning of 1980s. This rating system allows, from a certain number of financial ratios, to analyze the financial situation of a bank and to give it a grade by combining five domains of performance: the capital adequacy, assets quality, management quality, profitability (Earning ability) and liquidity, and a sixth domain of performance came to be added to the previous ones in 1996: Sensitivity to market risks. However, other authors like Godlewski (2004) assert that besides the internal factors, the elaboration of a model to predict of the failure of a bank needs taking to take consideration the institutional factors.

Other authors_such us Hanschel and Monnin (2003) and Kibritcioglu (2002) elaborated a clue of financial stress. It is about an aggregated indicator which considers various macroeconomic and microeconomic variables. The necessary approach for the elaboration of such an indicator is complex because it has to integrate a law of probability apart from the choice of a method of aggregation. Its major interest is to allow the monetary and supervisory authorities to feign macroeconomic shocks and to quantify their impact on the banking activities (Rouabah, 2006). However, it is necessary to notice that the financial stress indicator represents a general clue which gives an evaluation of the vulnerability of the banking sector as a whole and that is the reason why Rouabah (2006) has suggested examining the possibility of adopting a clue of stress for each individual bank.

Significant advances were made then in the study of the banking crises at a microeconomic level, that is at the level of an individual institution. The proposed models try to explain why the banks of a country, undergoing the same macroeconomic shock, do not all go bankrupt? Have those which went bankrupt got different characteristics from the others? If so, had some of these characteristics been different long before those banks went bankrupt?

In this context, the premature detection of the banking fragility at the individual level should facilitate the implementation of premature corrective measures intended to eliminate any risk of failure and contagion (systematic risk). The recent techniques borrowed from the artificial intelligence, such as the neural networks, have allowed to work out models that help to obtain good predictions by presenting the advantage of not requiring statistical limitations (Refait-Alexandre, 2004).

A neural network is a set of interconnected units which have a big capacity of apprenticeship and data processing. It is in fact a mathematical algorithm which allows to treat knowledge pertaining to the relationship between the input and output so as to classify the situations correctly.

This research aims to study the possibility of developing new tools for the detection of the fragility of banking institutions according to a new practical approach seeking to improve the capacity of the authorities to foresee and classify of banks in terms of performance (or 
fragility). More exactly, this research thus aims at determining if it is relevant to use the neural networks in developing a model of premature detection of the banking difficulties and the banking insolvency in Tunisia. Such a model could enlighten the decisions that are to be made by the authorities in view of preventing the bankruptcies of the Tunisian banking institutions.

The rest of the paper is organized as follows: in section 2, we will evaluate the stability of the banking system in Tunisia. Then, section 3 will include a presentation of a prediction model of the banking difficulties in Tunisia. In section 4, we will show the results and interpretations. Section 5 will be about the conclusion.

\section{The evaluation of the stability of the banking system in Tunisia}

\subsection{Presentation of the banking system}

The Tunisian banking sector consists of 5 big banks which hold $65 \%$ of market shares. Moreover, Fitch Ratings has found that « Tunisia has a significant number of banks for a relatively modest market». However, this market is relatively isolated and is very weakly exposed to foreign capital and the majority of the deposits and credits are local. The banks' assets in foreign currency represented $8 \%$ of the total of the banking assets at the end of April 2008, and were widely dominated by banks deposits, with a limited exposure to the international capital markets ( $0.3 \%$ of the total of the banking assets at the end of April 2008). This has proved to be a blessing for banks in Tunisia because they were able to stay completely protected from the world financial crisis. Indeed, the strict regulatory control on the exchange, namely the limits on the loans from financial institutions and companies, the ban on investment in the foreign capital markets, the limitations on exchange and derivative markets have led to a limited exposure of the local banks to the international financial markets. Offshore Banks that are subjected to a more flexible regulation and supervision from the Central Bank of Tunisia hold a low part of the total of the banking assets ( $7 \%$ at the end of April 2008).

The participation of foreigners in the capital of the Tunisian banks amounted to $37.36 \%$ for banks listed on 12 December 2008 against $38.04 \%$ before the emergence of the international financial crisis. This participation is mainly strategic and should remain even more as such owing to the potential offered by the Tunisian banking market. It is also part of the strategy of these foreign shareholders in the development of the retail bank (Société Générale UIB, BNP-Paribas-UBCI, Santander-Attijariwafa Bank-Attijari Bank company, Arab Bank PLC-ATB, CIC-BT, etc.). These alliances are seen as the major answer to the fragmentation of the Tunisian banking sector and the merger between the Tunisian banks remains a solution to several other troubles among which we can note facing the competition from foreign banks which could enter the national market following the liberalization of the services. Besides, these alliances will also expand the Tunisian banks sizes which will ultimately enable them foreign financial markets.

As regards the evolution of the Tunisian banking activities, we can note: having recorded a faster growth than that of the nominal GDP in the 1990s, the bank credit for the 
non-governmental sector has slowed down since the end of 2000 when banks began to worry about the quality of the credit, and it has increased since 2002 with a pace almost identical to that of the nominal GDP. In 2007, the volume of loans reached $56.8 \%$ of the nominal GDP. This ratio is in the average range of the MENA region (58\%) and remains sharply above the average level of certain countries of Central Europe (around 30\%), but obviously lower than the average level of the Euro-zone (109.6\%). In terms of deposits, the rate of penetration remains relatively low with $50.8 \%$ at the end of 2007 as compared to Morocco with $79.1 \%$, Kuwait (64.1\%) and Qatar (68.3\%).

The public banks continued to play a dominating role in financing the economy assuring more than 8.4 billion Tunisian dinars, that is more than $40 \%$ of the global outstanding credits allocated to the economy. Indeed, the BNA covered about $31 \%$ of the credits granted to the sector of agriculture and the fisheries whereas the STB assured, in 2007, $38 \%$ of the credits granted to the tourism sector. As for the $\mathrm{BH}$, it served more than $22 \%$ of the credits granted on real-estate development.

However, the spread of the use of banking services by the population, in spite of its progress, remains still low in Tunisia (50\% of the total population in 2007 against $98 \%$ for France, one agency for 9.6 thousand inhabitants against one agency for 7.3 thousand in Morocco and one agency for 2.4 thousand inhabitants in France). The Tunisian banks are essentially retail banks and the totality of the Banking Net Product results from the network of agencies.

\subsection{The reforms and the efforts of consolidation}

The liberalization of the financial sector was part of a of structural adjustment plan, partially prescribed by the IMF in 1987, which aimed at establishing a market economy and a major effort regarding privatization. The restructuring of the banking system aimed at intensifying the interbank competition and at allowing the banks to be more responsible and capable of making their own decisions of credit (Moore, 1991). The reforms also aimed at mobilizing the savings and at leading to an effective allocation of the resources.

Globally, the reforms introduced in Tunisia seem to have made a success. Jbili and Enders (1997) noted a remarkable progress in relation to the financial stability and the adjustment of the real interest rates in positive values _ $-4.3 \%$ on average during the pre-reform period (1970-1986), compared with +2 \% during the reform period (1987 - 1995). Besides, banks are less subject to governmental pressures as for the sectoral distribution of the credits because the part of the credits allotted for non-governmental sectors has increased from $40.3 \%$ of the GNP during the pre-reform period to $54.1 \%$ of the GNP during the reform period.

However, the development of the rules of banking supervision was relatively limited, partially because of the direct control which the Tunisian Central Bank exerted on the distribution of the credits and because of the presence of the government representatives most of the banks' boards of directors (Cook, Hababou \& Robert, 2000). This inefficiency has contributed to the accumulation of bad debts in the balance sheets of several banks. These debts have resulted on the one hand from the financing of public projects of infrastructure 
with industrial and commercial character and on the other hand from a lack of cautions management. In fact, the granting of the banking assistance continues to be widely based on guarantees, to the detriment of a thorough financial analysis intended to estimate the counterparty risk and based in particular on the quality of the project to be financed and its capacity to yield cash flow. Besides, the serious difficulties which have affected the tourist sector since 2001 have significantly contributed to heavier stock of bad debts. In spite of a decrease in 2005, the weight of these bad debts still represents about $13.2 \%$ of the total of the credits in 2009.

The existence of a solid financial system is an essential condition to support the economic growth and job creation. The important reforms introduced have allowed to improve the transparency of the financial transactions. Besides, the Tunisian banks focused on the improvement of the quality of their asset portfolios. Even though the sector managed to achieve the objective of reducing of the rate of bad debts at the levels of $13.2 \%$ in 2009 and $12 \%$ in 2011, these rates remain rather high with regard to an average of $5 \%$ for the other MENA countries.

Regarding provision for bad debts, a significant effort remains to be made to cover the unproductive debts suitably. However, the sector is taking the necessary measures to improve the viability of the granted loans. The ratio of funding for the whole system was $53.2 \%$ at the end of 2007, against $43 \%$ at the end of 2003. Given that the value of the real estate guarantees is inevitably subjected to uncertain fluctuations, this relatively low funding makes the system more exposed to external shocks, which increases its vulnerability. To improve its resistance, the authorities fixed an objective of $70 \%$ funding for 2012. Indeed, the rate of funding of the bad debts is one of the most important prudent standards considered, but this objective is far from being achieved by most of the Tunisian banks, especially those quoted banks.

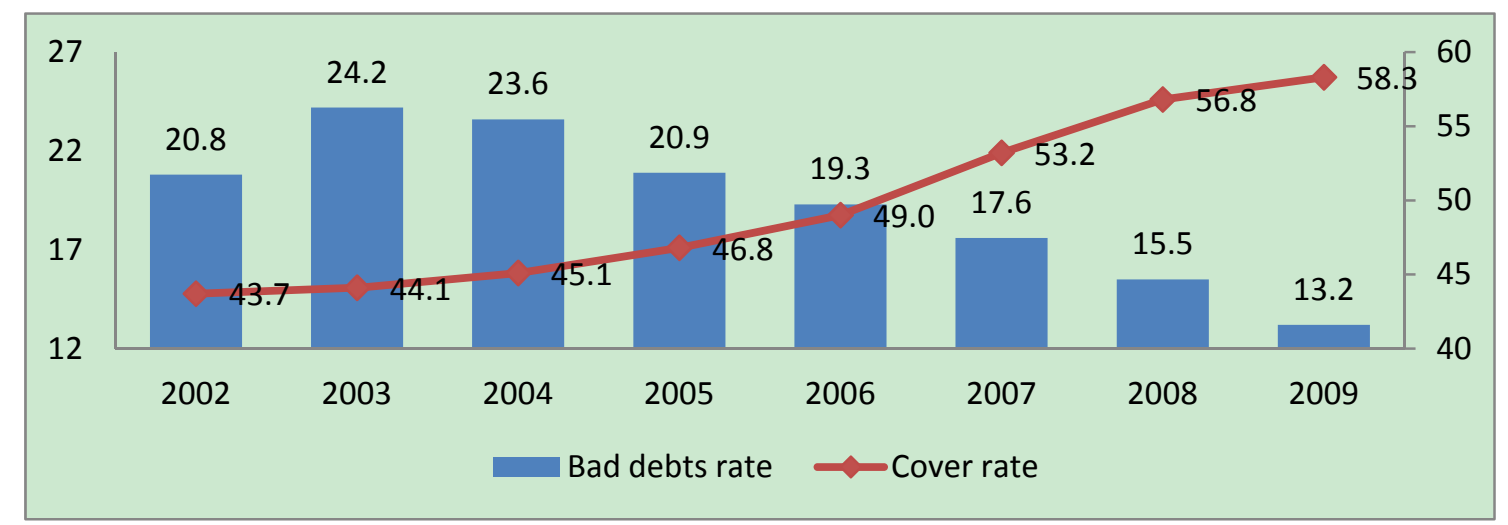

Source: Maxula Bourse (2010)

Figure 1. Quality of the Tunisian banks’ assets (in \%)

These measures have allowed the banks to strengthen their efforts regarding funding and so to improve the bad debts cover rate. In spite of this improvement, the rate of funding remains 
below the level of the $70 \%$ fixed by the Central Bank of Tunisia. According to the IMF, reaching this objective and even going further, would strengthen the banking system capacity of absorbing potential shocks which may affect the economy, considering the progressive opening of the capital account.

Besides, banks have continued their efforts regarding the strengthening of their capitals through capital increase operations, which has contributed to an of the $11.2 \%$ progress of stockholders' equity in 2009. As a result of this progress, the average ratio of bad debts cover increased from 56.8\% in 2008 to $58.3 \%$ in 2009.

Finally, we have witnessed a considerable improvement on fundamental of good governance among Tunisian banks. Indeed, the banking net product increased by $13.3 \%$ in 2008 and by $7.2 \%$ in 2009. Besides, the net income reached 461.6 million dinars in 2009, a $17 \%$ increase in comparison to that of 2008. This increase had a positive impact of the profitability of stockholders' equity because the ROE reached $11.7 \%$ in 2009 against $11.2 \%$ in 2008 and the return on assets (ROA) remained at the same level as that of the 2008_1\%.

\section{A model of the prediction of the banking difficulties in Tunisia}

Performance is a complex and multidimensional notion. It must be tackled with a thorough logic which exceeds the simple appreciation of profitability. It is a question of passing an objective judgment on the result, the functioning and the evolution of the company as a whole through a system of indicators that can be measured quantitatively or qualitatively.

\subsection{Methodology}

3.1.1 Description of the sample and the used data

Our sample consists of 18 Tunisian banks (see appendix). The data are taken from the publications of the Council of the Tunisian Financial Market and of the TPABFI (Tunisia's Professional Association of Banks and Financial Institutions). The period of study extends from 2002 to 2009.

Among the 18 banks in our sample, 11 banks are quoted on the Stock Exchange of Tunis. Moreover, on these 18 banks, 3 are public banks and 15 are private ones among which 11 are subsidiaries of foreign banks. Indeed, banks having a strong participation of the State are mainly the BNA, STB and BH. Banks like the BT and Amen Bank have private Tunisian capitals and banks such as the BIAT, UIB, UBCI, Attijari Bank and ATB have large foreign capitals. We can note that the total number of commercial banks in Tunisia passed from 14 in 2002 to 21 in 2009.

The first stage of our empirical study consists in identifying the banking difficulty. To do so, we are interested in the foreseeability of the capitalization ratio deteriorations, under the critical threshold of $8 \%$. This threshold coincides with the regulatory standards enacted by the 1998 Basle Agreement. For the Tunisian case, we judge that this threshold is too weak and this makes the banks' managers and the supervisors worry too much.

On that account, a bank is considered solvent for a given year if its ratio for the same year is 
higher than $8 \%$. However, if this ratio is lower than or equal to $8 \%$, this bank is considered as insolvent. The desired exit is thus formed by binary values: "1" for the solvent banks and "0" for those that are insolvent. This desired exit is going to serve us as a comparison with the calculated exit during the phase of apprenticeship and this is for the error determination.

\subsubsection{The selection of variables}

The financial ratios are variables mostly used in the models of risk forecast. A careful analysis of these ratios allows to estimate the financial health of banks and to find a way of improving it. Indeed, the ratios are strongly important tools which help to apply methods which improve profitability, liquidity, financial structure, debts and risk cover. Although the ratios often indicate the past performance, they can predict and supply indications on the potential problems (Gonzalez-Hermosillo, 1999).

The 8 financial ratios we have used are classified into three types of ratios: that of liquidity, solvency and profitability. These ratios have been chosen because of their popularity in the literature and in the previous researches on the financial analysis of the situations of banks. They are going to serve as predictive variables of the banking insolvency in our model (see the tables below).

Table 1 . Liquidity ratios

\begin{tabular}{|c|c|c|c|}
\hline Variables & Financial ratio & Definition & Authors \\
\hline R1 & Cash ratio & $\frac{\text { Current Assets }}{\text { Total Assets }}$ & $\begin{array}{l}\text { Godlewski (2003); } \\
\text { Al-Shayea, Ghaleb, } \\
\text { El-Refae and El-Itter (2010) } \\
\text { Abdennour and Houhou } \\
\text { (2008) }\end{array}$ \\
\hline R2 & Current ratio & $\frac{\text { Current Assets }}{\text { Short - Term Deposits }}$ & Al-Shayea et al.(2010) \\
\hline R3 & $\begin{array}{l}\text { Loans total assets } \\
\text { ratio }\end{array}$ & $\frac{\text { Total Loans }}{\text { Total Assets }}$ & $\begin{array}{l}\text { Abdennour and Houhou } \\
\text { (2008); Rouabeh (2006) }\end{array}$ \\
\hline $\mathrm{R} 4$ & Intermediation ratio & $\frac{\text { Total Loans }}{\text { Total Deposits }}$ & Godlewski (2003) \\
\hline
\end{tabular}

We consider that the increase of the ratio (R3) would be associated with an excessive risk taking by the banks and this could be translated by a severe vulnerability of the whole system. Moreover, Borio and Lowe (2002) as well as Eichengreen and Arteta (2000) consider that the fast evolution of bank credits constitutes a good indicator of crisis forecast.

The quality of the bank management is approximated by the variable (R4). This ratio 
measures the importance of the credits granted by the bank with regard to the main source of funding of its credits. It is a measure of the liquidity of the bank, because it connects the liquidity management with the banking performance. This ratio compares the illiquid assets (the credits) with the main stable source of funding (the deposits). So, the lower this ratio is, the more the bank is considered liquid and converse is true.

A low ratio of intermediation (R4) could consequently be interpreted as a sign of a good quality of management because the loans are financed by weakly paid funds, which implies bigger margins of interest. However, when the value of this ratio increases and becomes superior to 1 , the probability of a bank to be in trouble becomes important.

Table 2. Solvency ratios

\begin{tabular}{|c|c|c|c|}
\hline Variables & Financial ratio & Definition & Authors \\
\hline R5 & Capitalisation Ratio & $\frac{\text { Shareholders' equity }}{\text { Total assets }}$ & $\begin{array}{l}\text { Abdennour and Houhou } \\
\text { (2008); } \\
\text { Bongini, Claessens and Ferri } \\
(2000)\end{array}$ \\
\hline R6 & $\begin{array}{l}\text { Long-term } \\
\text { ratio }\end{array}$ & $\frac{\text { Shareholders' equity }}{\text { Total Loans }}$ & Al-Shayea et al.(2010) \\
\hline
\end{tabular}

The capitalization ratio (R5), called also the capital adequacy ratio, measures the weight of the bank's own capital with regard to the amount of its total assets. Athanasoglou, Brissimis, and Delis (2005) and Berger (1995) assert that in the presence of asymmetry of information, the well capitalized banks can reach funds on better conditions because they are considered as less risky institutions.

In our analysis, this ratio constitutes an approximation of Cooke ratio since we cannot calculate this ratio ourselves. Indeed, we have failed to reach information relative to the incurred risks of banks. So, we consider that a high level of this ratio allows the bank to absorb the possible shocks and to improve its financial solidity contributing to the reduction in its probability to be under-capitalized.

The ratio (R6) measures the degree of the long-term financial independence of the bank and translates its financial autonomy. Generally, a bank is considered financially autonomous when more than half of its resources come from equity capital. The higher the financial independence is, the healthier the bank is.

Table 3. The Profitability ratios

\begin{tabular}{llll}
\hline Variables & Financial Ratio $\quad$ Definition & Authors
\end{tabular}




\begin{tabular}{|c|c|c|c|}
\hline R7 & ROA & $\frac{\text { Pre }- \text { Tax Return }}{\text { Total Assets }}$ & $\begin{array}{l}\text { Al-Shayea et al.(2010); } \\
\text { Abdennour and Houhou (2008) }\end{array}$ \\
\hline R8 & ROE & $\frac{\text { Pre - Tax Return }}{\text { Shareholders' Equity }}$ & $\begin{array}{l}\text { Al-Shayea et al.(2010); } \\
\text { Abdennour and Houhou (2008) }\end{array}$ \\
\hline
\end{tabular}

The profitability of a credit institution represents its ability to make sufficient profits from its exploitation, after deduction of the necessary costs for this exploitation so as pursue its activity. Profitability is a bank strategy which has much more importance than the growth of its total assets. One of the variables which assures the solvency is the profitability of banks' operations. It is thus, a necessary condition for the safety of the whole financial system whether it relates to the return on equity (ROE) or return on assets (ROA), we notice that the Tunisian banks show low rates of profitability.

The measure of the profitability of assets (R7) is an indicator which allows to examine the degree of efficiency of the use of the available assets, that is its capacity to generate profits by means of the assets of the bank. An analysis based on the ROA can be biased because of the activities off-balance sheet, because these activities significantly generate profits but they are excluded from the denominator of the variable ROA. Besides, ROA places the totality of the assets of the bank on the same level of risk, while the risks relative to the components of the total assets are different (Goddard, Molyneux \& Wilson, 2004); (Athanasoglou, Brissimis \& Delis, 2008) and (Garcia-Herrero, Gavila \& Santabarbara, 2009).

The use of the second ratio of profitability (R8) to estimate the performance of a bank deserves a particular attention in its interpretation. The ROE is often considered as the major tool of banks' piloting. It constitutes a key indicator on which the managers' remuneration depends, the analysts' recommendations and the market requirements depend. It is well known that the least expensive and the safest way to increase the ROE is to increase the level of debts with regard to stockholders' equity.

Indeed, the profitability of shareholders' equity is equal to the return on assets (ROA) multiplied by the total of assets over equity capital. So, for the same economic profitability, the financial profitability is raised all the more as the debt is bigger. This leverage effect is situated in the heart of the activities of a bank, the intermediation is indeed only the use of funds borrowed from customers to be lent to the other customers at a higher rate in order to get a margin. Therefore, an analysis based on the ROE neglects the effect of the capital leverage and the risks associated to it.

So, the debts increase the ROE that when the situation is good and lower it when there are difficulties. This law has proved to be true in the recent financial crises. The shareholders who have suffered most are those in banks where the ROE and the debts were the highest before the crisis _ as reveals in the study of Beltratti and Stulz (2009). More exactly, when debts do not create value for the shareholders, they destroy the company.

Thus, a high level of stockholders' equity of banks does not constitute a brake in their 
competitiveness while a level of high debts, based on a sterile quest of ROE, is undoubtedly in the heart of the banking crises. That is why it is hard to judge the quality of the banking governance based on simple consideration of this indicator.

\subsection{The neural network adopted structure}

The neural models allow to plan the banking difficulties and to classify them in two categories: healthy banks and insolvent banks or banks in trouble. In our research, we used a multilayer neural network with a back-propagation algorithm, a sigmoïde function of activation and the mean square error (MSE) as function of performance. However, the number of neurons on the hidden layer is fixed after a series of tests.

The Multi-Layer Perceptron (MLP) is a feed-forward neural model. The MLP is one of neural networks that are most used for approximation, classification and prediction problems. These models are widely used in the field of finance and successfully in forecasts. The architecture of a MLP is presented in the figure below.

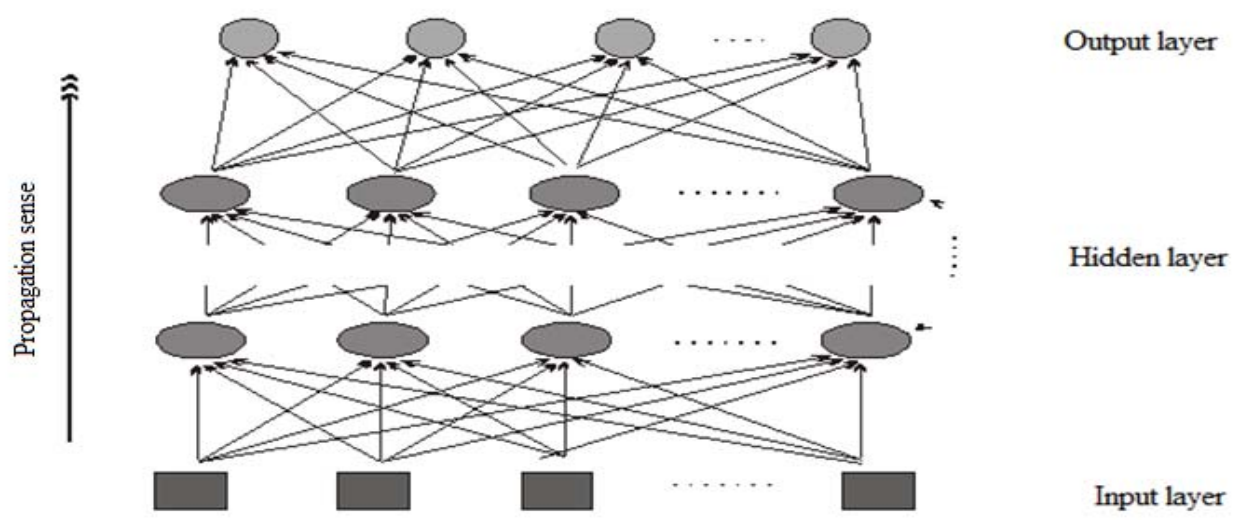

Figure 2. Architecture of a multi-layer perception

This model of neural networks is completely inter-connected. It allows signals to circulate always in a single direction: From the source (the input layer) to the destination (the output layer), without feedback. So, the information spreads from the layer to layer without the possibility of moving back.

A multi-layer network can include one or several intermediate layers called hidden layer. In our study, we will be using a multi-layer neural network with a single hidden layer. Indeed, Parizeau (2004) notes that the typical structure of the back-propagation neural network consists of three layers: an input layer, a hidden layer, and an output layer, provided that use a sigmoïde function of activation on the hidden layer.

On the input layer, the neural network receives the data. The number of neurons in this layer depends on the number of entries. For our model, the entry layer is composed of seven 
neurons which are going to receive the entering signals represented by the values of the seven ratios selected according to the previously described procedure, and a bias which has 1 for value.

We consider a MLP with a single hidden layer. This layer serves to make intermediate calculations and this allows the network to learn, adjust, and generalize from the previously learned facts to the new input. Indeed, every neuron in this layer receives the data supplied by the neurons of the previous input layer and makes simply a balanced sum of these entries, adds a threshold to this sum and passes the result by a transfer function to obtain its output. The latter will serve as new input to the neurons of the following layer. For our model, the number of neurons present on this layer is fixed after a series of tests.

In our application, the output layer consists of a single neuron emitting output signals which will be compared with the desired values. In fact, desired values are the values determined by the capitalization ratio (R5) previously calculated. The neural network is going to make a series of learning cycles with the aim of finding the desired values by trying to reduce the differences between these values and those calculated.

Be it known that it is question of ranking and given the fact that the desired values take the values 0 or 1 , it is more interesting to use an activation function (or a transfer function) of sigmoïd type (Parizeau, 2004). This function is defined by:

$$
E=1 / 2 \sum_{i=1}^{N}\left(x_{i}-y_{i}\right)^{2}
$$

With:

$N$ : Number of examples (bank-year for our study);

$x_{i}$ : Value desired by the output;

$y_{i}:$ Value calculated by the output;

\section{Results and Interpretation}

\subsection{The bank ranking quality}

The choice of the neuronal models to be adopted is made on the basis of network performance indicators (the percentages of good rankings and the learning and test errors). These models have to meet the following conditions: discriminate between the solvent banks and insolvent banks and predict the insolvency of banks.

For the construction of our final neural model, we used the Matlab 7.11.0 software. We have first of all proceeded to a ventilation of the initial sample. Indeed, the sample established by 144 (18 banks * 8 years) observations is shared in three sub-samples: 


\section{Macrothink}

- The first sub-sample, called "training data ", is going to serve in the learning phase (or of adaptation of the weights) and represents $70 \%$ of the total sample (100 observations).

- The second sub-sample, called "validation data ", represents $15 \%$ of the total sample (22 observations). It is used to measure the capacity of generalization of networks and to stop the procedure of learning when this capacity stops improving.

- The third sub-sample which is going to represent the basis of the test contains $15 \%$ of the total sample (22 observations). It has no effect on the procedure of learning, but it supplies an independent measure of the network performance during and after the learning.

Then, we have proceeded to the apprenticeship of a large number of networks to a single hidden layer to find the optimal architecture by varying the number of neuron on this layer. In fact, we have adopted the procedure of Yao, Tan and Poh (1999). This is an iterative method which consists in gradually increasing the number of hidden neurons of a unit until we find a minimal MSE (Essid, Zribi \& Boujelbene, 2009).

The following table presents the value of the MSE calculated at the level of 3 sub-samples for various numbers of hidden neurons.

Table 4. The value MSE for certain architectures

\begin{tabular}{llll}
\hline \multicolumn{3}{l}{ MSE value } & \\
\hline $\begin{array}{l}\text { Number of hidden } \\
\text { neurons }\end{array}$ & Training data & Validation data & Testing data \\
\hline 2 & 0.0545 & 0.0301 & 0.0682 \\
\hline 3 & 0.0615 & 0.121 & 0.138 \\
\hline 4 & 0.0992 & 0.123 & 0.260 \\
\hline 5 & 0.155 & 0.185 & 0.173 \\
\hline 6 & 0.130 & 0.190 & 0.136 \\
\hline 7 & 0.142 & 0.179 & 0.161 \\
\hline
\end{tabular}

According to the results which appear in the previous table, we notice that a neural network with two neurons presents the minimum of MSE and this at the level of three samples ( 0.0545 for the training data, 0.0301 for the training data and 0.0682 for the Testing data). Then, the configuration of the adopted network is presented in the following figure.

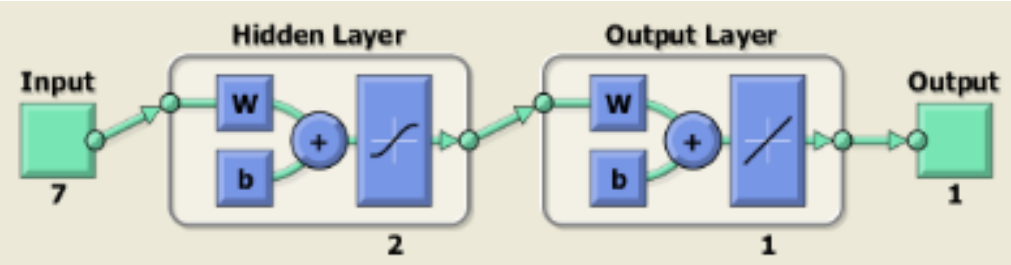


Figure 3. The configuration of the adopted network

Our network is composed by seven neurons on the entry layer, represented by the values of the seven selected financial ratios, two neurons on the hidden layer and one neuron on the exit layer) which produces the ranking result.

The test is a very important stage in the determination of a network performance. So, we have fed our network with the matrix of the Testing data $(\mathrm{T})$ to obtain an exit vector, a single column and 144 lines which we have compared with the real values (R5).

Thus, we have proceeded to the calculation of the rate of good ranking, by bringing the number of well classified observations to the total number of observations. The following table presents the obtained results.

Table 5. The calculation of the rate of good ranking

\begin{tabular}{|c|c|c|c|c|c|c|c|c|c|c|}
\hline \multirow{3}{*}{ Real situation } & \multicolumn{6}{|c|}{ Details according to the state of solvency } & \multirow{2}{*}{\multicolumn{4}{|c|}{$\begin{array}{l}\text { Global results } \\
\text { Samples }\end{array}$}} \\
\hline & \multicolumn{3}{|l|}{1} & \multicolumn{3}{|l|}{0} & & & & \\
\hline & A & $\mathrm{V}$ & $\mathrm{T}$ & A & V & $\mathrm{T}$ & A & $\mathrm{V}$ & $\mathrm{T}$ & Total \\
\hline 1 & 64 & 11 & 16 & 0 & 1 & 0 & 64 & 12 & 16 & 92 \\
\hline 0 & 6 & 0 & 2 & 30 & 10 & 4 & 36 & 10 & 6 & 52 \\
\hline Total real situation & 70 & 11 & 18 & 30 & 11 & 4 & 100 & 22 & 22 & 144 \\
\hline $\begin{array}{l}\text { Percentage of good } \\
\text { ranking }\end{array}$ & 91.43 & 100 & 88.89 & 100 & 90.91 & 100 & 94 & 95.45 & 90.91 & 93.75 \\
\hline $\begin{array}{l}\text { Percentage of good } \\
\text { global ranking }\end{array}$ & $91.91 \%$ & & & $97.7^{\prime}$ & & & 93.7 & & & \\
\hline
\end{tabular}

A: Training data

V: Validation data

T: Testing data

This table shows that the rate of good global ranking of the solvent banks is $91.91 \%$ and the rate of good ranking) of the insolvent banks is $97.77 \%$. So, the percentage of good total ranking stemming from the application of the neural networks is $93.75 \%$. This implies that the considered model manages to learn the patterns corresponding financial fragility of the Tunisian banks included in the sample. The MLP neural network constitutes a powerful tool in the ranking of banks according to their degree of performance.

Likewise, the results show a big capacity of the model in recognizing the level of fragility of certain banks which have not been taken into account during the apprenticeship (belonging to the test sample). Indeed, the rate of good ranking at the level of the test sample reached $90.91 \%$. We note that there is a total recognition of the unsuccessful banks. Their rate of 
good ranking in the test sample is $100 \%$. However, it is $88.89 \%$ for the successful banks. The results of the application of the methodology of the MLP artificial neural networks to predict the banking insolvency based on the selected financial ratios have showed a very good disposal of this technique in the construction of a model for the premature detection of the banking difficulties and the supervision of their solvency in Tunisia.

\subsection{The performances of the Tunisian banks}

To draw finer conclusions, we propose table 6 which presents the descriptive statistics of all the ratios used for each type of bank (solvent and insolvent).

Table 6. Descriptive Statistics of all the ratios in \%

\begin{tabular}{lllll}
\hline \multicolumn{2}{l}{ Solvent banks (99 observations) } & & & \\
\hline Ratios & Mean & Standard deviation & Max & Min \\
R1 & 91.560 & 4.791 & 99.964 & 75.776 \\
R2 & 248.783 & 309.287 & 1534.826 & 101.285 \\
R3 & 79.567 & 9.029 & 94.225 & 37.115 \\
R4 & 101.774 & 24.694 & 209.621 & 41.128 \\
R5 & 18.993 & 13.644 & 60.401 & 8.021 \\
R6 & 59.568 & 21.744 & 100.000 & 8.924 \\
R7 & -0.497 & 8.433 & 3.865 & -75.196 \\
R8 & -1.195 & 46.832 & 17.624 & -429.050 \\
\hline Insolvent banks $(45$ observations) & & & \\
\hline Ratios & Mean & Standard deviation & Max & Min \\
\hline R1 & 96.119 & 2.977 & 99.972 & 86.843 \\
R2 & 139.158 & 207.964 & 1502.175 & 95.612 \\
R3 & 82.703 & 9.363 & 95.665 & 56.476 \\
R4 & 87.916 & 9.830 & 103.335 & 59.936 \\
R5 & 5.918 & 2.201 & 7.996 & -1.098 \\
R6 & 59.873 & 40.264 & 100.000 & -148.730 \\
R7 & -0.128 & 2.093 & 1.436 & -10.351 \\
R8 & 21.508 & 143.259 & 942.262 & -176.480 \\
\hline
\end{tabular}

This table highlights that there is a disparity between 18 Tunisian banks of our sample during the period 2002-2009 regarding banking solvency. It allows to have an idea about the various "banks-years" of each category (solvent and insolvent).

We notice that the aggravating factors of risk are more present, on average, in the failing banks. These banks have less capital in the total of their assets (low R5), more loans in their balance sheets (high R3) and fewer liquid assets with regard to the total assets (R1) and with 


\section{Macrothink}

regard to the short-term debts (R2). On the other hand, the ratio of capital which covers their long-term credits (R6) is equivalent to that of successful banks, while the ratio of intermediation for healthy banks is more important than that of the failing banks (R4).

The obtained results have allowed us to make a ranking of banks considered in our application. This ranking is based on, S, the number of times a bank shows itself solvent, and this over the 8 years of our study period.

Table 7 shows the category of each bank for every year included in the period of study. By considering all these characteristics, we have been able to establish the ranking of the banks belonging to the sample of study according to a decreasing degree. A first examination of this ranking for the period 2002-2009 shows that the banks which occupy the first rank are the most successful banks. According to the criterion R5, we find at the bottom of the ranking the BFT (insolvent bank over the whole study period) and to a lesser extent the ABC and ATTIJARI. All these banks are small in size and are not quoted on The Stock Exchange of Tunis. They can go bankrupt if the Supervision authorities do not take urgent restructuring measures.

Table 7. The rankings of the Tunisian banks (2002-2009)

\begin{tabular}{lll}
\hline $\begin{array}{l}\text { According } \\
\text { R5 }\end{array}$ & to & Capitalization ratio \\
\hline Rank & Banks & $S$ \\
\hline 1 & STB & 8 \\
- & BT & 8 \\
- & BTE & 8 \\
- & BTL & 8 \\
- & BTK & 8 \\
- & AB & 8 \\
- & UBCI & 8 \\
- & TQB & 8 \\
2 & BTS & 7 \\
3 & BNA & 6 \\
4 & ATB & 5 \\
5 & BIAT & 4 \\
- & CITIBANK & 4 \\
6 & UIB & 3 \\
7 & BH & 2 \\
- & Attijari Bank & 2 \\
- & ABC & 2 \\
& &
\end{tabular}

According to the MLP exit

\begin{tabular}{lll}
\hline Rank & Banks & $S$ \\
\hline 1 & STB & 8
\end{tabular}

$-\quad$ BT 8

- $\quad$ BTE

$\begin{array}{lll}- & \text { BTL } & 8\end{array}$

- $\quad$ BTK

$\begin{array}{lll}- & \mathrm{AB} & 8\end{array}$

$\begin{array}{lll}- & \text { UBCI }\end{array}$

$\begin{array}{lll}2 & T Q B & 7\end{array}$

$3 \quad$ BNA $\quad 6$

4 ATB 5

5 BIAT 4

- $\quad$ CITIBANK 4

6 UIB 3

- $\quad \mathrm{BH}$

$7 \quad$ Attijari Bank 2

- $\quad$ ABC 2

8 BTS 0


8

BFT

0

BFT

0

For a better characterization of the ranking of banks according to the capitalization ratio R5, we propose the following illustration.

\begin{tabular}{|c|c|c|c|c|c|c|c|c|c|}
\hline Banks & $S$ & 2002 & 2003 & 2004 & 2005 & 2006 & 2007 & 2008 & 2009 \\
\hline STB & 8 & & & & & & & & \\
\hline BT & 8 & & & & & & & & \\
\hline BTE & 8 & & & & & & & & \\
\hline BTL & 8 & & & & & & & & \\
\hline BTK & 8 & & & & & & & & \\
\hline $\mathrm{AB}$ & 8 & & & & & & & & \\
\hline UBCI & 8 & & & & & & & & \\
\hline TQB & 8 & & & & & & & & \\
\hline BTS & 7 & & & & & & & & \\
\hline BNA & 6 & & & & & & & & \\
\hline ATB & 5 & & & & & & & & \\
\hline BIAT & 4 & & & & & & & & \\
\hline CITIBANK & 4 & & & & & & & & \\
\hline UIB & 3 & & & & & & & & \\
\hline $\mathrm{BH}$ & 2 & & & & & & & & \\
\hline Attijari Bank & 2 & & & & & & & & \\
\hline $\mathrm{ABC}$ & 2 & & & & & & & & \\
\hline BFT & 0 & & & & & & & & \\
\hline
\end{tabular}

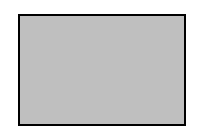

Solvent

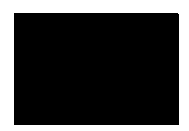

Insolvent

This illustration shows the predominance of the grey color in the matrix, which implies that the Tunisian banking sector is globally solvent. However, the black color_ implying banking fragility_ is relatively important over the periods 2002-2003 and 2007-2009. During these two periods, the majority of banking institutions witnessed a degradation in their results. Consequently, they carried out considerable efforts to strengthen their stockholders' equity to restore their financial balance. Taken as a whole, these consolidation efforts resulted in slight improvement of the sectoral mean Cooke ratio which changed from $12.2 \%$ in 2008 to $12.51 \%$ in 2009, thus respecting the $8 \%$ standard [see table 8]. 
Table 8. The ratio Cooke (in \%)

\begin{tabular}{lll}
\hline & 2008 & 2009 \\
\hline AB & 12.6 & 13.1 \\
ATB & 11.0 & 14.3 \\
ATTIJARI Bank & 6.8 & 9.2 \\
BIAT & 13.7 & 11.9 \\
BH & 10.4 & 10.2 \\
BNA & 8.2 & 11.4 \\
BT & 22.1 & 21.8 \\
STB & 9.3 & 9.0 \\
UBCI & 10.95 & 10.51 \\
UIB & 8.6 & 9.2 \\
\hline Sectoral Mean & 12.2 & 12.51 \\
\hline
\end{tabular}

Source: Maxula Bourse (2010)

All the banks have to respect this minimum rate to avoid the effect of contagion of the financial instability to the whole system in the case of a possible insolvency of one of them. In the same way, the cover rate of the bad debts by the sector passed from $46 \%$ in 2005 to $58 \%$ in 2009 (Maxula Bourse, 2010).

Besides, the STB (one of the biggest public banks in Tunisia) is considered_according to our ranking_ among the group of the healthy banks over the whole study period though it is relatively undercapitalized (Cooke ratio near 9\%) in comparison with the ATB and especially to the BT which have a Cooke ratio higher than $20 \%$. The latter show a solidity allowing them a potential credit granting capacity much superior to that of their competitors.

Contrary to the BT which remains characterized by the lowest rate of bad debts of the sector (8\%) and associated with the highest rate of funding (about $83 \%$ ), the STB and the UIB still suffer from the weight of the bad debts from the weakness of their cover with regard to the sector average. The STB, for example, had about $20 \%$ of bad debts in 2009 but they were covered only at the level of $49.7 \%$.

The low quality of the assets of the STB dates back, partially, to its merger with the Economic Development Bank of Tunisia (EDBT) and The National Bank of Tourism Development (NBTD) in 2000. In 2009, the yield on its assets was only $0.3 \%$ while the subsidiary of Attijari Bank in Tunisia reached $1.2 \%$. Besides, it specialized in financing the tourism sector, which has largely weakened due to a bad situation. In spite of the massive transfers of the bad debts to its covering subsidiary, the STB still suffers from its active contribution in financing the tourism sector considered to be having priority by the public authorities. The part of bad debts accumulated from the tourism sector remains the most 
important reaching $49.5 \%$. Besides, the STB still has a low rate of cover (49.7\%), lower than the sectoral average (58.78\%,). The table below summarizes the position of the STB with regard to the other public banks.

Table 9. The rate of bad debts and the rate of cover of the public banks (2009)

\begin{tabular}{lll}
\hline & Rate of bad debts & Rate of cover \\
\hline BH & $8.9 \%$ & $70 \%$ \\
BNA & $11.9 \%$ & $68.6 \%$ \\
STB & $19.8 \%$ & $49.7 \%$ \\
\hline Sectoral Mean & $13.96 \%$ & $58.78 \%$ \\
\hline
\end{tabular}

Source: Maxula Bourse (2010)

The results obtained in our rankings (according to the ratio R5 or according to the MLP exit as well) could be explained by the fact that R5 ratio, used as a discriminating variable, is an imperfect approximation of the Cooke ratio. Indeed, the $\mathrm{R} 5$ ratio constitutes a simple measure of the weight of the bank's capital. It determines the allocation of the bank's sources of funding into debts and stockholders' equity. It gives no information about the quality of the assets held by the bank.

On the other hand, the Cooke ratio is a ratio of risk cover. It is defined as being the ratio of the stockholders' equity of a bank over its assets balanced by the risks. It is an indicator which allows to estimate the extent to which point the banking system is threatened by the credit risks and the quality of the held claims. We indeed notice why the R5 ratio does not establish a good approximation of the Cooke ratio. It ensues from this that its use did not allow to characterize the STB vulnerability our ranking.

Finally, we find in this ranking the BFT which occupies the last position. The vulnerability of this bank is explained by the bad practices which created a volume of bad debts 17.5 times as important as its capital. Consequently, its indicators of profitability did not stop degrading: Its Banking Net Product (BNP) has constantly decreased passing from 11. 4 million Tunisian dinars in 2007 to 8.318 million Tunisian dinars in 2008 (a 27\% reduction), to finish with another decrease of $13 \%$ in 2009. This disastrous situation also represents the main threat for the future of the STB bank which holds $78.18 \%$ of its capital. The BFT will probably be the first bank to go bankrupt of a bank in Tunisia, but it is very likely that the monetary authorities will come to its rescue taking into account the predictable affects on all the other Tunisian banking institutions.

\section{Conclusion}

Within the framework of this study, we have proposed a model of premature detection of the banking difficulties in Tunisia. This model aims at identifying the institutions whose financial 


\section{Macrothink}

Asian Journal of Finance \& Accounting

ISSN 1946-052X

2013, Vol. 5, No. 1

situation seems worrisome on the one hand, and on the other hand allowing the supervision authorities to take the necessary corrective measures for banks in trouble before their situation worsens and results in bankruptcy.

For that purpose, we have tested the validity of the technique of the neural networks of neurons in the construction of a model of premature detection of the banking insolvencies in Tunisia.

Although the artificial neural networks seem well adapted to the problems of forecast of the financial distress and failure, they have certain limitations. Indeed, there is no theory allowing to build neural networks. As numerous parameters are involved in construction of networks, we do know how to examine them very well. A judicious choice of the parameters depends on the intuition and the experience which researcher has during the model construction process.

The results obtained_by the application of the methodology of neural networks to predict the banking fragility based on 8 financial ratios for a sample of 18 Tunisian banks examined over the period 2002-2009_ showed a very good disposition of the neural networks in the construction of a model of premature detection of the banking difficulties and the supervision of their solvency in Tunisia. Indeed, the percentage of a good ranking by Multilayer neural networks the total sample was superior to $93 \%$. Then the neural networks turn out to be a strong as method for the purpose of prediction.

Although these results seem to be interesting from in terms of classification of the Tunisian banks, they must be considered subject to the reliability of the published financial statements, especially the question of bad debts. Besides, it would be interesting to take into account the nature and the quality of the institutional, legal and statutory environment in which the Tunisian banks operate and that are crucial for the banks' risk-taking. So, a system of premature detection alarm of banking difficulties including CAMEL financial variables and institutional, legal and statutory variables could represent a more efficient tool to identify the institutions having financial difficulties, especially in emergent nations. 


\section{Appendix}

18 Tunisian banks of the sample

\begin{tabular}{ll}
\hline AB & AMEN BANK \\
ABC & ARAB BANKING CORPORATION \\
ATB & ARAB TUNISIAN BANK \\
ATTIJARI BANK & ATTIJARI BANK OF TUNISIA (ATTIJARI BANK) \\
BIAT & ARAB INTERNATIONAL BANK OF TUNISIA \\
BFT & FRANCO-TUNISIAN BANK \\
BH & BANK OF HOUSING \\
BNA & NATIONAL AGRICULTURAL BANK \\
BT & BANK OF TUNISIA \\
BTE & TUNISIA AND EMIRATES BANK \\
BTK & TUNISO-KUWATI BANK \\
BTL & TUNISO-LIBYAN BANK \\
BTS & TUNISIAN SOLIDARITY BANK \\
Citibank & CITIBANK (onshore branch) \\
STB & TUNISIAN BANKING COMPANY \\
TQB & TUNISIAN QATARI BANK \\
UBCI & BANKING UNION FOR TRADE AND INDUSTRY \\
UIB & INTERNATIONAL BANKING UNION \\
\hline
\end{tabular}

\section{References}

Abdennour, F., \& Houhou, S. (2008). Un modèle d'alerte précoce de difficultés bancaires pour les pays émergents. Économie internationale, 114, 69-92.

Al-Shayea, Q. K., Ghaleb, A., El-Refae, G. A., \& El-Itter, S. F. (2010). Neural Networks in Bank Insolvency Prediction. IJCSNS-International Journal of Computer Science and Network Security, 10(5), 240-245.

Athanasoglou, P. P., Brissimis, N. S., \& Delis, M. D. (2008). Bank-specific, industry-specific and macroeconomic determinants of bank profitability. Journal of international financial Markets, Institutions and Money, 18, 121-136. http://dx.doi.org/10.1016/j.intfin.2006.07.001

Athanasoglou, P. P., Brissimis, N. S., \& Delis, M. D. (2005). Bank-Specific, Industry-Specific and Macroeconomic Determinants of Bank Profitability. Bank of Greece Working Paper, No. 25.

Barr, R. S., \& Siems, T. F. (1994). Predicting Bank Failure Using DEA to Quantify Management Quality. Financial Industry Studies Working Paper, Federal Reserve Bank of 
Dallas.

Beltratti, A., \& Stulz, R. (2009). Why Did Some Banks Perform Better during the Credit Crisis ? A Cross-Country Study of the Impact of Governance and Regulation. ECGI Working Paper Series in Finance Nº. 254/2009.

Berger, A. (1995). The Relationship Between Capital and Earnings in Banking. Journal of Money, Credit and Banking, 27, 404-431. http://dx.doi.org/10.2307/2077876

Bongini, P., Claessens, S., \& Ferri, G. (2000). The Political Economy of Distress in East Asian Financial Institutions, World Bank Policy Research Paper No. 2265.

Borio, C., \& Lowe, P. (2002). Asset prices, financial and monetary stability: Exploring the nexus , BIS Working Papers, ${ }^{\circ}$ 114, Bâle, juillet.

Cook, W. D., Hababou, M., \& Roberts, G. S. (2000). Financial Liberalization and Efficiency inTunisian Banking Industry: DEA Tests, Working Paper, Schulich School of Business, York University, September.

Eichengreen, B., \& Arteta, C. (2000). Banking Crises in Emerging Markets: Presumptions and Evidence, Center for International and Development Economics Research Working Paper, C00-115, août.

Essid, Z., Zribi, M., \& Boujelbene, Y. (2009). La prévision des difficultés bancaires: application d'une approche neuronale, Communications of the IBIMA, 11, 67-74.

Garcia-Herrero, A., Gavila, S., \& Santabarbara, D. (2009). What Explain The Low Profitability of Chinese Banks. Journal of Banking \& Finance, 33(11), 2080-2092. http://dx.doi.org/10.1016/j.jbankfin.2009.05.005

Goddard, J., Molyneux, P., \& Wilson, J. O. S. (2004). The Profitability of European Banks: A Cross-Sectional and Dynamic Panel Analysis. Manchester School, 72(3), 363-381. http://dx.doi.org/10.1111/j.1467-9957.2004.00397.x

Godlewski, C. J. (2004). Le Rôle de l’Environnement Réglementaire, Légal et Institutionnel dans la Défaillance des Banques Le Cas des Pays Emergents, Banque \& Marchés, 73, 20-31.

Godlewski, C. J. (2003). Modélisation de la prévision de défaillance bancaire et facteurs réglementaires : une application aux banques des pays émergents, LARGE Research Center (Laboratoire de Recherche en Gestion et Economie), Université de Strasbourg, Juillet.

Gonzalez-Hermosillo, B. (1999). Determinants of Ex-Ante Banking System Distress: A Macro-Micro Empirical Exploration of Some Recent Episodes, working paper n99/33, International Monetary Fund.

Goyeau, D., \& Tarazi, A. (1992). Evaluation du risque de défaillance bancaire en Europe, Revue d'Economie Politique, 102(2).

Hanschel, E., \& Monnin, P. (2003). Measuring and forecasting stress in the banking sector: Evidence from Switzerland, BIS Papers ${ }^{\circ} 22$. 
International Monetary Fund. [IMF], Country Report No.06 / 207, June (2006).

Jbili, A., \& Enders, K. (1997). Financial Sector Reforms in Algeria, Morocco and Tunisia : A preliminary Assessment, IMF Working paper $\mathrm{N}^{\circ}$ 97/81.

Kibritçioglu, A. (2002). Excessive Risk-Taking, Banking Sector Fragility, and Banking Crises, Working Paper $\mathrm{N}^{\circ} 02-0114$, University of Illinois at Urbana-Champaign.

Maxula Bourse. (2010). Revue Bancaire. Document de travail, Département Recherches et Analyses, Novembre.

Moore, C. H. (1991). Tunisian Banking: Politics of Adjustment and the Adjustment of Politics, in Zartman I. W. ed. Tunisia, The political Economy of Reform, Lynne Rienneer Publishers.

Pantalone, C. C., \& Platt, M. B. (1987). Predicting Commercial Bank Failure Since Deregulation, New England Economic Review, Jul/Aug, 37-47.

Parizeau, M. (2004). Réseaux de neurones, Département de génie électrique et de génie informatique Université Laval, Septembre.

Refait-Alexandre, C. (2004). La prévision de la faillite fondée sur l'analyse financière de l'entreprise : un état des lieux, Economie \& prévision, 2004/1, 162, 129-147.

Rojas-Suarez, L. (2001). Rating Banks in Emerging markets: What Credit Rating Agency Should Learn Firm Financial Indicators?, Working paper, Institute for international Economics.

Rojas-Suarez, L. (2000). Can International Capital Standards Strengthen Banks in Emerging markets?, Working paper, Institute for international Economics.

Rouabah, A. (2006). La sensibilité de l'activité bancaire aux chocs macroéconomiques: une analyse de Panel sur des données de banques luxembourgeoises 1994-2005, Banque Centrale du Luxembourg, Cahier d'études n²6, mai.

Yao, J., Tan, C.J., \& Poh, H. L. (1999). Neural networks for technical analysis: a study on KLCI, International Journal of Theoretical and Applied Finance, 2(2), http://dx.doi.org/10.1142/S0219024999000145 